\title{
Early Language Development and Child Aggression
}

\author{
Ceyhun Ersan ${ }^{1, *}$ \\ ${ }^{1}$ Department of Preschool Education, Alanya Alaaddin Keykubat University, Antalya, Turkey \\ *Correspondence: Department of Preschool Education, Alanya Alaaddin Keykubat University, Antalya, Turkey. \\ E-mail: ceyhun.ersan@alanya.edu.tr
}

Received: December 10, 2019

Accepted: January 29, 2020

Online Published: February 3, 2020

doi:10.5430/wje.v10n1p1

URL: https://doi.org/10.5430/wje.v10n1p1

\begin{abstract}
Aggression observed in early childhood is considered to be an important problem. Multiple factors may play a decisive role in children's aggressive behaviors. The aim of this study was to examine whether the receptive and expressive language skills of preschool children (39-75 months-old) had predictive role on the levels of physical and relational aggression. The sample of the present study consists of 109 preschool children ( 47 girls and 62 boys). The language development levels of children in the sample were evaluated by TEDIL (Turkish Early Language Development Test) and their aggression levels were evaluated via Preschool Social Behavior Scale which were filled by their teachers. Pearson product moment correlation coefficient and stepwise regression analysis were used to analyze the data. According to the findings of the study, there was a significant and negative relationship between children's receptive and expressive language skills and physical and relational aggression levels. The results of regression analysis revealed that physical aggression was negatively and significantly predicted by expressive language skills. In addition, relational aggression is negatively and significantly predicted by both receptive and expressive language skills. The increase in children's language skills significantly explains the decrease in physical and relational aggressive behaviors. The relationship between language skills and aggressive behaviors of Turkish preschool children was examined for the first time in this study. It is thought that the present study will contribute to the literature since it reveals the current situation in terms of the relationships between children's language skills and aggression levels and provide opportunities to make comparisons with the results of international studies.
\end{abstract}

Keywords: preschool children, language development, receptive language, expressive language, physical aggression, relational aggression

\section{Introduction}

Aggression is defined as a kind of behavior which aims to harm and hurt self or another person who does not want to harm anyone or anything (Anderson \& Bushman, 2002; Ersan, 2017; Krahé, 2013). Anyone who is confronted with an obstruction or get angry for some reason can physically harm the other person who is thought to be the cause of that situation (punch someone), or anyone who damages another one's possessions or disrupts their social relationships with others (making false rumors about a person, telling lie, etc.). At this point, it is argued for several years whether human being's aggression is an instinct or a learned behavior (Bandura, Ross \& Ross, 1961; Hogg \& Vaughan, 2007). Whatever it is, with instinct or learned behavior, in this century, aggression is accepted as an unwanted, socially condemned and negative phenomenon (Cüceloğlu, 2011; Mitscherlich, 2000). From a developmental perspective, it is known that human (physical) aggression increases in the first three years of life and tends to decrease starting from the fourth year (Alink et al., 2006). Therefore, it can be said that the phenomenon of aggression emerged during preschool years in which human development forms (Aral, Kandır \& Can Yaşar, 2000) as in, physical, cognitive, emotional, social and linguistic sides. Especially, in preschools children start spending time with their peers. During that time, they show their aggressive tendencies against their newly met peers. Besides preschool children characterized aggression like hitting, pushing, spitting, yelling and so on, they also show related aggression behaviors like not letting a peer be a part of their game whom they are not fond of or gossip about a peer who does not do what they want him to do (Crick et al., 2006). As a matter of fact, it is emphasized that there is an alarming increase in the number of preschool children who are referred to clinics (Landy \& Menna, 2001) because they are diagnosed with aggression every year and that child aggression is one of the most destructive behaviors that 
are most worried by parents, teachers and psychiatrists (Craig, Henderson, \& Murphy, 2000; Ercan, Ercan, Akyol Ardıç, \& Uçar, 2016). Aggressive behaviors of preschool children may be related to many variables. In the literature, it is possible to see that aggression is examined in terms of various variables such as temperament (González-Peña, Egido, Carrasco, \& Tello, 2013), gender (Kung, Li, Golden, \& Hines, 2018), parental attitudes (Hosokawa \& Katsura, 2018) and emotion regulation skills of children (Ersan, 2020). However, it is important that children understand others' feelings and thoughts during the interactions they make with them and beyond that it is important that they can express their own feelings and thoughts. Understanding others and expressing self to others refers to the importance of language development in children. Children are expected to understand and express the verbal language of their culture in relation to their language development. In this respect, language skills are based on two categories: receptive language and expressive language. The receptive language can be defined as child's ability to recognize and understand words. Through receptive language, children can understand what a word represents when $\mathrm{s} /$ he hears a particular word. Expressive language, on the other hand, is the ability to use voice and words acquired through the receptive language during social interactions with others. The more children gain control over the production of sounds and words, the more they develop their expressive language skills (Levey \& Polirstok, 2011; Otto, 2010).

When literature is examined, it can be said that there are few studies on language development and aggression of preschool children. However, the results show that there is a negative relationship between language development and aggression. For example, in a longitudinal study with a fairly large sample $(\mathrm{n}=14000)$ where the relationship between expressive language skills and behavioral problems of preschool children was examined (Girard, Pingault, Doyle, Falissard, \& Tremblay, 2016), it was found that behavioral problems of 3-year-old children were related to the "expressive language" ability they displayed when they reached age 5. On the other hand, the lack of expressive language skills of children at the age of 3 was found to be significantly associated with behavior problems at age 5 . The results of another study examining (Estrem, 2005) the relationship between preschool children's receptive and expressive language skills and both physical and relational aggression show that there is a significant and negative relationship between children's language skills and aggression. However, the possible relationship between language development and aggression levels of preschool children are uncertain for Turkish preschool children. In this study, the possible relationship between receptive and expressive language skills and physical and relational aggression of preschool children was studied.

\section{Method}

The present study is a quantitative one and "correlational research method" is used. Correlational research is a type of non-experimental research method. Correlation studies aim to reveal the possible relationships between two or more variables without any intervention and they can be conducted in two types: exploratory and predictive. In exploratory correlational research, possible relationships between variables are analyzed to understand the event/situation. In the predictive correlational research, the relationship is tried to be predicted from one of the variables examined. This means an effort to explain the unknown value of the other variable over a known value of one variable (Büyüköztürk, Kılıç Çakmak, Akgün, Karadeniz, \& Demirel, 2014). In this study, both exploratory and predictive correlation analyzes were performed.

\subsection{Participants}

The study group consisted of 109 children [62 boys (57\%) and 47 girls (43\%)] attending a kindergarten in Alanya, Antalya. The average age of the children is 4.26. Most of the families were usually at the lower socio-economic level. In terms of the monthly income, families had between 1800 and 4300 Turkish Liras. In terms of educational level, 60 (55\%) mothers were secondary school graduates, 42 (38\%) of them were high school graduates and $7(7 \%)$ of them were university graduates. $87(80 \%)$ of the mothers were housewives $(15 \%), 15(13 \%)$ of them were workers and 7 (7\%) of them were civil servants. Regarding educational level, 42 fathers (38\%) were secondary school graduates, 55 of them (51\%) were high school graduates and 12 of them (11\%) were university graduates. 75 of the fathers $(69 \%)$ were workers and 23 of them $(21 \%)$ were civil servants. 11 of the fathers $(10 \%)$ were retired or unemployed.

\subsection{Data Collection Tools}

\subsubsection{Turkish Early Language Development Test (Tedil-3)}

Turkish Early Language Development Test was originally developed by Hresko, Reid and Hammill in 1999 under the name of "Test of Language Development-3 (Teld-3)" and it is adapted to Turkish by Topbaş and Güven in 2009 as "Turkish Early Language Development Test (Tedil-3)". Tedil-3 aims to evaluate the language development levels 
of children between 2 years 0 month to 7 years 11 months. Tedil-3 has six general purposes; the first one is identifying children that are left behind in early language skills compared to their peers; the second one is identifying the strengths and weaknesses of children in terms of verbal language competences; the third one is setting the program and the scope of the process for possible language speech therapy; the fourth one is providing an assessment tool that enables the examination of language skills in early childhood; the fifth one is providing multiple clinical/developmental assessments and the last one is providing the basis for the provision of intervention services to children with language development problems.

Tedil-3 consists of two different measuring sets designed as A and B. However, both sets of measures are designed as parallel forms to assess both receptive and expressive language skills. There are separate picture booklets and application registration forms for each measuring sets. The measurement sets A and B contain 76 items each for evaluating both receptive language and expressive language development. Table 1 shows the subtests and questions of both measurement sets.

Table 1. Turkish Early Language Development Test Subtests and Questions in Measurement Sets

\begin{tabular}{ll}
\hline A Form & B Form \\
\hline Receptive Language & Receptive Language \\
24 Semantics questions, & 25 Semantics questions \\
13 syntax/morphology questions & 12 syntax/ morphology questions \\
Expressive Language & Expressive Language \\
22 Semantics questions, & 24 Semantics questions, \\
17 syntax/morphology questions & 15 syntax/morphology questions \\
\hline
\end{tabular}

In the scope of the items in Table 1, questions are asked to the child by using the form A or B and the child is asked to show or describe the appropriate picture. In addition, the child is expected to fulfill the verbal instructions requested or to respond verbally to the questions posed.

Standardization, reliability and validity analyzes of Tedil-3 were performed in the Turkish adaptation studies. A and B forms and both subtests were applied to children, whose ages were ranging from 2 to 7 , in seven different regions of Turkey regarding standardization, reliability and validity studies of the test. At the same time both forms and subtests were applied to selected subgroups in which the children were bilingual; had language disorders and developmental disabilities in Turkey, and it is seen that the test was not biased. In this sense, Tedil-3 can distinguish different subgroups selected in terms of language skills. As a result of the analysis of construct validity, the correlations between Teld-3 A and B forms and subtests with age were calculated between .78 and .79.

In Tedil-3 reliability analyzes, Cronbach Alpha internal consistency coefficients were .93 in Form A for the receptive language subtest, .92 in Form B. The expressive language subtest was calculated as .94 in Form A and .92 in Form B. Test retest correlation coefficients were .95 for receptive language subtest for A and B Forms; The expressive language subtest was calculated as .86 for Forms A and B (Topbaş \& Güven, 2014). Tedil-3 is a standardized measuring instrument to evaluate the language skills of children in many studies (Aslan \& Yücel, 2019; Moedt \& Holmes, 2018; Nadig, 2013; Özyurt \& Eliküçük, 2017; Yılmaz, Avcığlu, \& Büyükçakmak, 2019; Spaulding, 2012; Turan, Küçüköncü, Cankuvvet, \& Yolal, 2012).

In the implementation of the Tedil-3 test, the actual age of the child has to be calculated in years and months. After this calculation, the measurement starts with the question corresponding to the year and month (e.g. 3 years and 4 months) of the child. This starting point refers to the item on which the test should be started based on the chronological age of the child. Each correct answer of the child's questions is coded as 1 point and the wrong answer is not given any scores and coded as 0 points. The test is terminated if three incorrect answers are given from the starting point. The raw scores thus obtained are converted to standard scores for both language skills using the tables provided in the practitioner's manual (Topbaş \& Güven, 2014). Practitioners of the Tedil-3 test need special training in the process. The researcher should have the necessary training and application certificate.

\subsubsection{Preschool Social Behavior Scale - Teacher Form}

The Preschool Social Behavior Scale, originally developed by Crick, Casas and Mosher in 1997, aims to determine the social behaviors of preschool children with teacher ratings. Preschool Social Behavior Scale-Teacher Form was adapted to Turkish by Karakuş (2008). According to the results of the adaptation process, exploratory factor analysis was conducted to determine the construct validity of the scale. According to the results, items in the scale were 
grouped into 4 sub-dimensions as physical aggression, relational aggression, prosocial behavior and depressive emotions. These four sub-dimensions explain $67 \%$ of the total variance. According to reliability analysis the total Cronbach's alpha coefficient of the Preschool Social Behavior Scale-Teacher Form was .87; physical aggression was .90, relational aggression was .84, prosocial behavior was .89 and depressive emotions were .68 (Karakuş, 2008 ). In this study, only items related to physical aggression and relational aggression subscales of Preschool Social Behavior Scale-Teacher Form were used. In 2017, Ersan conducted a confirmatory factor analysis of the physical and relational aggression sub-dimensions of the Preschool Social Behavior Scale-Teacher Form. According to the results obtained from the analysis; $\chi 2 / \mathrm{sd}=3.97, \mathrm{RMSEA}=.076, \mathrm{GFI}=.93, \mathrm{AGFI}=.91, \mathrm{CFI}=.97(\mathrm{Ersan}, 2017)$. In the literature, it is seen that there are many studies evaluating children's level of aggression via Preschool Social Behavior Scale-Teacher Form both in the world and in Turkey (Alisinanoğlu \& Kesicioğlu, 2010; Carpender \& Nagle, 2006; Ersan, 2020; Karaca, Gündüz, \& Aral, 2011; Rich, Shepherd \& Nable, 2008; Song, Kim, \& Yoo, 2015; Swit, 2016; Uysal \& Dinçer, 2013; Zatto, 2018).

\subsection{Data Collection and Analysis}

Before the data collection, necessary permissions were obtained within the framework of the protocol signed between the University where the researcher is working and the Directorate of National Education. After obtaining the relevant permissions, the researcher visited the randomly selected kindergarten and informed the study group about the study. A written text explaining the purpose of the study and the relevant process was sent to the parents of 126 children in the kindergarten. In this text, each parent who wanted to participate was asked to confirm that s/he allowed his/her child to take part in the study. This permission was received from 117 parents with their signature on it. Nine of the parents did not allow their children to participate in the study. In addition, 8 out of 117 children whose parents were approved did not want to participate in the assessment process. For this reason, 17 out of 126 children were not included in the measurement and data collection processes so the study was completed with 109 children whose parents approved and agreed to participate. Children's receptive and expressive language skills were obtained via applying the Tedil-3 test by the researcher. The researcher invited each child to an empty, quiet and suitable room in the school and the test was performed after a short interview. In this context, the administration of each test was carried out in a time period of about 20 to 35 minutes. This measurement process was conducted in a period of approximately four months considering the suitability of the researcher, the kindergarten and the children. The assessment tool for children's physical and relational aggression was evaluated by their teachers.

The data were subjected to normality test before analysis. At this point, the kurtosis and skewness coefficients of each variable were taken into consideration. As seen in Table 2, variables have values between -2 and +2 in terms of kurtosis and skewness coefficients. This can be considered as an indication that the data shows normal distribution and is suitable for parametric statistics (George \& Mallery, 2010). Pearson correlation coefficient was used to examine the relationship between children's receptive and expressive language skills and levels of physical and relational aggression. There was no correlation between .80 and above among the independent variables of the study; the Durbin-Watson coefficient was found to be between 1.5 and 2.5 (see Table 2) and thus there was no autocorrelation problem that did not allow regression analysis (Kalayc1, 2008). Stepwise Regression analysis was used to determine the ability of children's receptive and expressive language skills to predict their physical and relational aggression levels.

\section{Results}

\subsection{Exploratory Correlation Findings}

Pearson correlation analysis was conducted to determine whether there was a significant relationship between the receptive and expressive language skills and physical and relational aggression levels of preschool children. According to the analysis, it is seen that there was a positive and significant $(.57 ; \mathrm{p}<.01)$ relationship between children's receptive and expressive language skill scores (Table 2). There was a positive, high and significant (.78; $\mathrm{p}$ $<.01)$ relationship between physical and relational aggression scores of children with dependent variables. On the other hand, it was found that there was a negative and significant relationship between the scores of children's physical language $(-.39 ; \mathrm{p}<.01)$ and relational aggression scores $(-.44 ; \mathrm{p}<.01)$. Similarly, there was a negative and significant relationship between children's expressive language scores of $(-.48 ; \mathrm{p}<.01)$ and relational aggression scores $(-.43 ; \mathrm{p}<.01)$. Therefore, it can be said that as the receptive and expressive language skills of preschool children increased, their levels of physical and relational aggression decreased. 
Table 2. Correlation Coefficients and Descriptive Statistics of Variables

\begin{tabular}{lcccccccc}
\hline Variables & 1 & 2 & 3 & 4 & $\bar{X}$ & Sd & Kurtosis & Skewness \\
\hline 1. Receptive Language & 1 & & & & 106.01 & 11.52 & -.018 & -.047 \\
2. Expressive Language & $.57^{*}$ & 1 & & & 107.61 & 12.77 & .348 & .045 \\
3. Physical Aggression & $-.39^{*}$ & $-.48^{*}$ & 1 & & 10.76 & 6.51 & 1.28 & 1.41 \\
4. Relational Aggression & $-.44^{*}$ & $-.43^{*}$ & $.78^{*}$ & 1 & 10.55 & 6.18 & 1.34 & 1.10 \\
\hline
\end{tabular}
$\mathrm{p}<.01 *$

\subsection{Findings on Predictive Correlation}

Multiple Linear Stepwise Regression analysis was performed to determine whether receptive and expressive language skills of preschool children predicted their physical and relational aggression levels. When the analysis results in Table 3 are considered, it is seen that stepwise regression analysis is completed in one step and the physical aggression levels of children significantly predicted only by expressive language skills. Expressive language skills of children explain $23 \%$ of their physical aggression $\left(\mathrm{R}=.48, \mathrm{R}^{2}=.23, \mathrm{~F}(1-107)=32.773, \mathrm{p}<.001\right)$. When beta and $\mathrm{t}$ values are examined, it can be said that this predictive was negative. On the other hand, it is seen that the receptive language skills of children were not significant predictors of physical aggression.

Table 3. Results of Multiple Linear Stepwise Regression Analysis of Predictive Physical Aggression of Children's Receptive and Expressive Language Skills

\begin{tabular}{llrrrrrrrr}
\hline \multirow{2}{*}{ Model } & $\begin{array}{l}\text { Predictive } \\
\text { Variable }\end{array}$ & $\mathrm{B}$ & Std. Error & Beta & $\mathrm{t}$ & $\mathrm{p}$ & $\mathrm{R}$ & $\mathrm{R}^{2}$ & Durbin Watson \\
& & & & & & & & & \\
\hline \multirow{2}{*}{1} & (Stable) & 37.32 & 4.67 & & 7.98 & .00 & & \\
& Expressive Language & -.247 & .043 & -.48 & -5.72 & .00 & .48 & .23 & 1.661
\end{tabular}

Model 1: F (1-107) $=32.773, \mathrm{p}<.001$

Table 4 presents the results of the analysis of whether children's receptive and expressive language skills had the power to predict relational aggression. When the results of the analysis in Table 4 are considered, it is seen that stepwise regression analysis is completed in two stages. Both receptive and expressive language skills of children were significant predictors of relational aggression. According to the results of the first stage regression analysis, children's receptive language skills predict their relational aggression at $20 \%$ ratio $\left(\mathrm{R}=.44, \mathrm{R}^{2}=.20, \mathrm{~F}(1-107)=\right.$ $26.330, \mathrm{p}<.001$ ); when the beta and $\mathrm{t}$ values are taken into consideration, it can be said that this prediction was negative. In the second stage, the variance explained by adding expressive language skills to the model increased to $25 \%$. When beta and $t$ values are examined, it is understood that expressive language skills of children predict their relational aggression negatively and meaningfully.

Table 4. Results of Multiple Linear Step Regression Analysis of Predictive Relational Aggression of Children's Receptive and Expressive Language Skills

\begin{tabular}{|c|c|c|c|c|c|c|c|c|c|}
\hline Model & Predictive Variable & B & Std. Error & Beta & $\mathrm{t}$ & $\mathrm{p}$ & $\mathrm{R}$ & $\mathrm{R}^{2}$ & Durbin Watson \\
\hline \multirow{2}{*}{1} & (Stable) & 35.84 & 4.95 & & 7.23 & .00 & & & \multirow{6}{*}{1.681} \\
\hline & Receptive Language & -.239 & .046 & -.44 & -5.13 & .00 & .44 & .20 & \\
\hline \multirow{4}{*}{2} & (Stable) & 41.13 & 5.23 & & 7.85 & .00 & & & \\
\hline & Receptive Language & -.157 & .055 & -.29 & -2.84 & .00 & & & \\
\hline & Expressive & -.130 & .050 & -.26 & -2.61 & .01 & .50 & .25 & \\
\hline & Language & & & & & & & & \\
\hline
\end{tabular}

Model 1: $\mathrm{F}(1-107)=26.330, \mathrm{p}<.001$

Model 2: F $(2-106)=17.292, \mathrm{p}<.001$

\section{Discussion}

In this study, possible relationships between language development and aggressive behaviors of preschool children were examined. It can be said that there was a discrepancy regarding the variables discussed in previous studies 
examining preschool children's language development and aggression. In all these studies conducted abroad, physical aggression with receptive language (Spilt, Koomen, \& Harrison, 2015), relational aggression with receptive language (Crick et al., 1999; Hawley, 2003), physical aggression with receptive language and expressive language (Clark, 2011), physical and relational aggression with receptive language (Park et al., 2005), relational aggression with expressive language (Dionne, Tremblay, Boivin, Laplant, \& Perusse, 2003; Girard et al., 2016; Harper, 2011), receptive language and expressive language and relationship between relational aggression (Bonica, Arnold, Fisher, Zeljo, \& Yershova, 2003; Razmjoee, Harnett, \& Shahaeian, 2016; Shahaeian, Razmjoee, Wang, Elliott, \& Hughes, 2017) were studied. There was only one study found (Estrem, 2005) examining the relationship between children's receptive and expressive language skills and both physical and relational aggression. As previously mentioned before, there was no study carried out in Turkey on these variables. These reasons made it quite difficult to discuss the findings obtained.

As a result of the exploratory correlations, it was concluded that there was a negative and significant relationship between children's receptive and expressive language skills and physical and relational aggression. As the receptive language skills of children increased, the likelihood of applying physical aggression decreased. This finding of the study was supported with the results of other studies in the literature (Estrem, 2005; Séguin, Parent, Tremblay \& Zelazo, 2009; Spilt et al., 2015). Children's receptive language skills also had a negative and significant relationship with relational aggression. Strong receptive language skills reduce children's potential relational aggression behaviors. In the literature, there were studies both supporting (Estrem, 2005; Hawley, 2003) and not supporting (Crick et al., 1999; Razmjoee et al., 2016) this finding.

According to another finding obtained in the study, there were some cases that were clear in the language to explain the approval and in some cases it was decisive (Clark, 2011; Dionne et al., 2003; Estrem, 2005; Girard et al., 2016; Harper, 2011). Similarly, there is a significant negative relationship between children's expressive language skills and their relational aggression behaviors. This finding was supported only by one study result (Estrem, 2005). These findings obtained within the context of exploratory correlation suggest that the student's ability to reinforce receptive and expressive language skills decreased their ability to resort to physical and relational aggression. In addition to this, the findings of the predictive correlation obtained in this study may help us to understand the stronger relationships between these variables.

Only expressive language skills of children were found to be a significant predictor of physical aggression. In this context, $23 \%$ of the physical aggression of children included in the study group was negatively predicted by expressive language skills. In order for the expressive language to emerge, the receptive language must be developed as a premise (Otto, 2010). In this study, it was observed that there was a positive correlation of .57 between the receptive and the expressive language. Children's expressive language skills predict their physical aggression negatively. However, it was seen that receptive language skills had no predictive power over physical aggression. In this context, the fact that the children included in the study group express their own feelings and thoughts about the event or behavior by means of words rather than whether they understand other children's verbal or nonverbal behaviors in their peer relationships explains the decrease in their tendency to resort to physical aggression. For example, when a child tells his peer who wants to take the toy in his hand, "hey, I'm playing with it" or "Look! There's another one, you can have it", it reduces physical aggression. In a Canadian study (Clark, 2011) children showed that both receptive and expressive language skills were negative predictors of physical aggression. On the other hand, in a longitudinal study conducted in the UK, it was found that the lack of expressive language skills (Conti Ramsden \& Botting, 2004) in children at the age of seven was significantly associated with the physical aggression they faced when they reached 11 years of age. Therefore, it can be said that while the lack of expressive language skills of children can increase their physical aggression, it can also increase the possibility of becoming a victim of physical aggression.

According to another finding in the study, children's receptive language skills are negative and significant predictor of their relational aggression. Therefore, the increase in children's receptive language skills explains $20 \%$ of the decrease in the probability of children resorting to relational aggression (Archer \& Coyne, 2005). In this aspect, there were no behaviors that could be observed clearly in relational aggression such as direct hitting, spitting and screaming. In relational aggression, there were behaviors that were less conspicuous and aiming social harm, such as the exclusion of the other child from the play group or the prevention of the friendship of a child, who do not do anything they want, with other children. With receptive language skills, children understand what others say in their interaction with them. The increase in their ability to understand the feelings and thoughts of others significantly explains the decrease in the relational aggression of children towards other children. In other words, a child, who can "understand" his peer's speech after getting his seat that he wanted to sit but he took, is significantly less likely to 
resort to relational aggression. A longitudinal study (Park et al., 2005) showed that preschool children's receptive language skills negatively predicted their relational aggression in middle childhood and supported the findings of this study. In addition, relational aggression of children was significantly predicted by expressive language skills.

After the receptive language, the expressive language skills included in the model produced a $5 \%$ increase in the variance in children's relational aggression. Like in physical aggression, as the ability to transfer emotions and thoughts appropriately to others increases, the possibility of children showing relational aggressive behaviors decreases significantly. The results of a limited number of studies that do not support this result emphasize that expressive language skills in preschool period are positively related to relational aggression in middle childhood (Park et al., 2005). Therefore, studies on language development and aggression of preschool children are needed in larger samples, longitudinal design and other related variables (socio-economic level of parents, parental attitudes, child temperament etc.).

In the context of these findings, it can be said that early language development plays an important role in reducing child aggression. In this respect, first of all, families are expected to have a supportive perspective on the language development of their children. When the literature is examined, it is seen that both receptive and expressive language skills are strengthened in those children whose parents show a supportive interaction (Dale, Tosto, Hayiou-Thomas, \& Plomin, 2015; Ersan, 2015; Hoffman, \& Cassano, 2013; Pan, Rowe, Singer, \& Snow, 2005; Safwat \& Sheikhany, 2014; Tamis-LeMonda \& Rodriguez, 2009; Tetik \& Iş̧ıoğlu Erdoğan, 2017).

Empowering children's early language skills with the support of parents can make significant contributions to reducing the possible aggressive behavior of these children. On the other hand, studies in the field revealed that education in preschool institutions contributes positively to language development of children (Brodin \& Renblad, 2019; Foorman, Anthony, Seals, \& Mouzaki, 2002; Olofsson \& Niedersøe, 1999; Taner \& Başal, 2005; Tunçeli \& Zembat, 2018). From this point of view, parents should not only be able to engage in language-based interactions with their children, but also initiate institutional preschool education. Preschool education is not compulsory in Turkey yet so it is up to parents whether a child should go to preschool education institutions or not. Attendance of children to preschool education institutions might support the development of language positively and reveal the possible language deficiencies. In this study, it was seen that the problem might be related to language development, especially in children who show physical and relational aggression. Preschool teachers can organize activities to support children's language development with aggressive behaviors. Teachers can collaborate with parents and school psychologists on this issue. School psychologists can search whether there is an insufficiency in the language development of children who come to them with the diagnosis of aggression. At this point, support can be obtained from speech therapists and other specialists.

\section{References}

Alink, L. R., Mesman, J., Van Zeijl, J., Stolk, M. N., Juffer, F., Koot, H. M., ... Van IJzendoorn, M. H. (2006). The early childhood aggression curve: Development of physical aggression in 10-to 50-month-old children. Child development, 77(4), 954-966. https://doi.org/10.1111/j.1467-8624.2006.00912.x

Alisinanoğlu, F., \& Kesicioğlu, O. S. (2010). Okul öncesi dönem çocuklarının davranış sorunlarının çeşitli değişkenler açısından incelenmesi (Giresun İli örneği) [The research on the behavioral problems of preschoolers in terms of various variables]. Kuramsal Ĕgitimbilim, 3(1), 93-110.

Anderson, C. A., \& Bushman, B. J. (2002). Human aggression. Annual Review Psychology, 53, $27-51$. https://doi.org/10.1146/annurev.psych.53.100901.135231

Aral, N., Kandır, A., \& Can Yaşar, M. (2000). Okul Öncesi Eğitim ve Ana Sinıfi Programları[Preschool Education and Kindergarten Programs]. İstanbul: Ya-Pa Yayınları.

Archer, J., \& Coyne, S. M. (2005). An integrated review of indirect, relational, and social aggression. Personality and social psychology review, 9(3), 212-230. https://doi.org/10.1207/s15327957pspr0903_2

Aslan, F., \& Yücel, E. (2019). Auditory reasoning skills of cochlear implant users. The Journal of International Advanced Otology, 15(1), 70. https://doi.org/10.5152/iao.2018.5400

Bandura, A., Ross, D., \& Ross, S. A. (1961). Transmission of aggression through imitation of aggressive models. The Journal of Abnormal and Social Psychology, 63(3), 575-582. https://doi.org/10.1037/h0045925

Bonica, C., Arnold, D. H., Fisher, P. H., Zeljo, A., \& Yershova, K. (2003). Relational aggression, relational victimization, and language development in preschoolers. Social Development, 12(4), 551-562. 
https://doi.org/10.1111/1467-9507.00248

Brodin, J., \& Renblad, K. (2019). Improvement of preschool children's speech and language skills. Early Child Development and Care, 1-9. https://doi.org/10.1080/03004430.2018.1564917

Büyüköztürk, Ş., Kılıç-Çakmak, E., Akgün, Ö. E., Karadeniz, Ş., \& Demirel, F. (2014). Bilimsel Araştırma Yöntemleri [Scientific Research Methods]. Ankara: Pegem Yayınc1lık.

Carpenter, E. M., \& Nangle, D. W. (2006). Caught between stages: Relational aggression emerging as a developmental advance in at-risk preschoolers. Journal of Research in Childhood Education, 21(2), 177-188.

Clark, R. (2011). The language-aggression hypothesis in preschoolers: maternal scaffolding and self-regulation. Unpublished Doctoral Dissertation, Winsdor, University of Windsor, Department of Psychology.

Conti-Ramsden, G., \& Botting, N. (2004). Social difficulties and victimization in children with SLI at 11 years of age. Journal of Speech, Language, and Hearing Research, 47, 145-161. https://doi.org/10.1044/1092-4388(2004/013)

Craig, W. M., Henderson, K., \& Murphy, J. G. (2000). Prospective teachers' attitudes toward bullying and victimization. School Psychology International, 21(1), 5-21. https://doi.org/10.1177/0143034300211001

Crick, N. R., Ostrov, J. M., Burr, J. E., Cullerton-Sen, C., Jansen-Yeh, E., \& Ralston, P. (2006). A longitudinal study of relational and physical aggression in preschool. Journal of Applied Developmental Psychology, 27(3), 254-268. https://doi.org/10.1016/j.appdev.2006.02.006

Crick, N. R., Werner, N. E., Casas, J. F., O’Brien, K. M., Nelson, D. A., Grotpeter, J. K., \& Markon, K. (1999). Childhood aggression and gender: A new look at an old problem. Gender and motivation, 45, 75-141.

Cüceloğlu, D. (2011). İnsan ve Davranışı [Human and Behavior](22. bs.). İstanbul: Remzi Kitabevi.

Dale, P. S., Tosto, M. G., Hayiou-Thomas, M. E., \& Plomin, R. (2015). Why does parental language input style predict child language development? A twin study of gene-environment correlation. Journal of Communication Disorders, 57, 106-117. https://doi.org/10.1016/j.jcomdis.2015.07.004

Dionne, G., Tremblay, R., Boivin, M., Laplante, D., \& Perusse, D. (2003). Physical aggression and expressive vocabulary in 19-month-old twins. Developmental psychology, 39(2), 261-273. https://doi.org/10.1037//0012-1649.39.2.261

Ercan, E., Ercan, E. S., Akyol-Ardıç, Ü., \& Uçar, S. (2016). Çocuklar İçin Saldırganlık Ölçeği Anne-Baba Formu: Türkçe geçerlilik ve güvenilirlik çalışması [Children Aggression Scale-Parent Version (CAS-P): Turkish validity and reliability study]. Anadolu Psikiyatri Dergisi, 17(Ek.1), 77-84.

Ersan, C. (2015). The effect of fathers' language training program on the receptive language development of children. Education and Science, 40(180), 51-71. http://dx.doi.org/10.15390/EB.2015.4260

Ersan, C. (2017). Okul öncesi dönem çocuklarının saldırganlık düzeylerinin duygu ifade etme ve duygu düzenleme açisindan incelenmesi [The study of the aggression levels of preschool children in terms of emotion expression and emotion regulation]. Unpuplished Doctoral Dissertation, Denizli, Pamukkale Üniversitesi, Eğitim Bilimleri Enstitüsü.

Ersan, C. (2020). Physical aggression, relational aggression and anger in preschool children: The mediating roleof emotion regulation. The Journal of General Psychology, 147(1), 18-42. https://doi.org/10.1080/00221309.2019.1609897

Estrem, T. L. (2005). Relational and physical aggression among preschoolers: The effect of language skills and gender. Early Education \& Development, 16(2), 207-232. https://doi.org/10.1207/s15566935eed1602_6

Foorman, B. R., Anthony, J., Seals, L., \& Mouzaki, A. (2002, September). Language development and emergent literacy in preschool. In Seminars in Pediatric Neurology, 9(3), 173-184. WB Saunders.

George, D., \& Mallery, M. (2010). SPSS for Windows Step by Step: A Simple Guide and Reference (10nd ed.). Boston: Pearson, 2010.

Girard, L. C., Pingault, J. B., Doyle, O., Falissard, B., \& Tremblay, R. E. (2017). Expressive language and prosocial behaviour in early childhood: Longitudinal associations in the UK Millennium Cohort Study. European Journal of Developmental Psychology, 14(4), 381-398. https://doi.org/10.1080/17405629.2016.1215300

González-Peña, P., Egido, B. D., Carrasco, M. A., \& Tello, F. P. H. (2013). Aggressive behavior in children: the role 
of temperament and family socialization. The Spanish Journal of Psychology, 16, 1-12. https://doi.org/10.1017/sjp.2013.28

Harper, C. R. (2011). The early parent-child relationship and aggression: the mediating role of language. Unpublished Master Thesis, Georgia, Georgia State University, College of Arts and Sciences.

Hawley, P. H. (2003). Strategies of control, aggression, and morality in preschoolers: An evolutionary perspective. Journal of experimental child psychology, 85(3), 213-235. https://doi.org/10.1016/S0022-0965(03)00073-0

Hoffman, J. L., \& Cassano, C. (2013). The beginning: Reading with babies and toddlers. In J. A. Schickedanz \& M. F. Collins (Eds.), So much more than ABCs: The early phases of reading and writing. Washington, DC: National Association for the Education of Young Children.

Hogg, M. A., \& Vaughan, G. M. (2007). Sosyal Psikoloji [Social Psychology]. İ Yıldız \& A Gelmez (Translated by), Ankara: Ütopya Press.

Hosokawa, R., \& Katsura, T. (2019). Role of parenting style in children's behavioral problems through the transition from preschool to elementary school according to gender in Japan. International Journal of Environmental Research and Public Health, 16, 1-17. https://doi.org/10.3390/ijerph16010021

Kalayc1, Ş. (2008). SPSS Uygulamalı Çok Değişkenli İstatistik Teknikleri [SPSS Applied Multivariate Statistical Techniques]. İstanbul: Asil Yayın Dağıtım, 2008.

Karaca, N. H., Gündüz, A., \& Aral, N. (2011). Okul öncesi dönem çocuklarının sosyal davranışının incelenmesi [The investigation of social behaviors of preschool children]. Kuramsal Eğitimbilim Dergisi, 4(2), 65-76.

Karakuş, A. (2008). Okul Öncesi Sosyal Davranış Ölçeği Öğretmen Formu'nun güvenirlik ve geçerlik çalışması [Reliability and validity study of Preschool Social Behavior Scale Teacher Form]. Unpublished Master Thesis, İstanbul, Marmara Üniversitesi, Eğitim Bilimleri Enstitüsü.

Krahé, B. (2013). Social Psychology: A Modular Course. The Social Psychology of Aggression (2nd ed.). USA: Psychology Press.

Kung, K. T., Li, G., Golding, J., \& Hines, M. (2018). Preschool gender-typed play behavior at age 3-5 years predicts physical aggression at age 13 years. Archives of Sexual Behavior, 47(4), 905-914. https://doi.org/10.1007/s10508-017-1005-6

Landy, S., \& Menna, R. (2001). Play between aggressive young children and their mothers. Clinical Child Psychology and Psychiatry, 6(2), 223-239. https://doi.org/10.1177/1359104501006002005

Levey, S., \& Polirstok, S. (2011). Language Development: Understanding Language Diversity in the Classroom. USA: Sage Publications.

Mitscherlich, A. (2000). Barış Düşüncesi ve Saldırganlık. H. Portakal (Translated by), (2nd ed.). İstanbul: Cem Yayınevi, 2000.

Moedt, K., \& Holmes, R. M. (2018). The effects of purposeful play after shared storybook readings on kindergarten children's reading comprehension, creativity, and language skills and abilities. Early Child Development and Care, 1-16. https://doi.org/10.1080/03004430.2018.1496914

Nadig, A. (2013) Test of Early Language Development (TELD). In: Volkmar F.R. (Eds.), Encyclopedia of Autism Spectrum Disorders. Springer, New York, NY.

Olofsson, Å., \& Niedersøe, J. (1999). Early language development and kindergarten phonological awareness as predictors of reading problems: From 3 to 11 years of age. Journal of Learning Disabilities, 32(5), 464-472.

Otto, B. (2010). Language Development: In Early Childhood (3nd ed.). USA: Pearson.

Özyurt, G., \& Eliküçük, Ç. D. (2017). Gelişimsel dil gecikmesi tanısı olan çocuklarda dil özelliklerinin teknolojik alet kullanmaları, aile işlevselliği, anne depresyonu ile ilişkisi ve sağlıklı kontrollerle karşılaştııılması [Relation of language features with maternal depression, family functioning, and digital technology usage in children with developmental language delay-comparison with healthy controls]. Düşünen Adam, 30(4), 299-308. https://doi.org/10.5350/DAJPN2017300403

Pan, B. A., Rowe, M. L., Singer, J. D., \& Snow, C. E. (2005). Maternal correlates of growth in toddler vocabulary production in low-income families. Child Development, 76(4), 763-782.

Park, J. H., Essex, M. J., Zahn-Waxler, C., Armstrong, J. M., Klein, M. H., \& Goldsmith, H. H. (2005). Relational 
and overt aggression in middle childhood: Early child and family risk factors. Early Education \& Development, 16(2), 233-258. https://doi.org/10.1080/10409289.2005.10472869

Razmjoee, M., Harnett, P. H., \& Shahaeian, A. (2016). Language development mediates the relationship between gender and relational aggression: A study of Iranian preschool children. Australian Journal of Psychology, 68(4), 312-318. https://doi.org/10.1111/ajpy.12109

Rich, E. C., Shepherd, E. J., \& Nangle, D. W. (2008). Validation of the SSRS-T, preschool level as a measure of positive social behavior and conduct problems. Education and Treatment of Children, 31(2), 183-202.

Safwat, R. F., \& Sheikhany, A. R. (2014). Effect of parent interaction on language development in children. The Egyptian Journal of Otolaryngology, 30(3), 255-263.

Séguin, J. R., Parent, S., Tremblay, R. E., \& Zelazo, P. D. (2009). Different neurocognitive functions regulating physical aggression and hyperactivity in early childhood. Journal of Child Psychology and Psychiatry, 50(6), 679-687. https://doi.org/10.1111/j.1469-7610.2008.02030.x

Shahaeian, A., Razmjoee, M., Wang, C., Elliott, S. N., \& Hughes, C. (2017). Understanding relational aggression during early childhood: An examination of the association with language and other social and cognitive skills. Early childhood research quarterly, 40, 204-214. https://doi.org/10.1016/j.ecresq.2017.04.002

Song, H., Kim, J., \& Yoo, H. (2015). Measures of aggression in young Korean children: A review of 10 years of empirical research. Universal Journal of Psychology, 3(4), 97-105.

Spaulding, T. J. (2012). Comparison of severity ratings on norm-referenced tests for children with specific language impairment. Journal of Communication Disorders, 45(1), 59-68.

Spilt, J. L., Koomen, H. M., \& Harrison, L. J. (2015). Language development in the early school years: The importance of close relationships with teachers. Developmental psychology, 51(2), 185-196. https://doi.org/10.1037/a0038540

Swit, C. S. (2016). Social cognition and relational aggression: an investigation of the cognitive bases of preschoolers' aggressive behaviour. Unpuplished Doctoral Dissertation, Macquarie University Sydney, Australia.

Tamis-LeMonda, C. S., \& Rodriguez, E. T. (2008). Parents' role in fostering young children's learning and language development. Encyclopedia on early childhood development, 1, 1-11.

Taner, M., \& Başal, H. A. (2005). Farklı sosyoekonomik düzeylerde okulöncesi eğitimi alan ve almayan ilköğretim birinci sınıf öğrencilerinin dil gelişimlerinin cinsiyete göre karşılaştırılması [Compare language development in first grade primary school students from different socioeconomic levels who take and do not take pre-school education according to the gender.]. Uludağ Üniversitesi Eğitim Fakültesi Dergisi, 18(2), 395-420.

Tetik, G., \& Işıkoğlu Erdoğan, N. (2017). Diyaloğa dayalı okumanın 48-60 aylık çocukların dil gelişimine etkisi [The Effects of Dialogic Reading on 48-60 Months Old Children's Language Development]. Kastamonu Eğitim Dergisi, 25(2), 1-16.

Topbaş, S., \& Güven, S. (2014). TEDIL: Türkçe Erken Dil Gelişimi Testi kullanım Kılavuzu [Test of Early Development-Third Edition: Turkish]. Ankara: Detay yayınc1lık.

Tunçeli, H. İ., \& Zembat, R. (2018). 48-72 aylık çocukların gelişimlerinin çeşitli değişkenler açısından Lap-3 Gelişim Değerlendirme Ölçeği ile incelenmesi [The investigation of 48-72 months children's development in terms of various variables byLap-3 Development Assessment Scale]. Abant İzzet Baysal Üniversitesi Eğitim Fakültesi Dergisi, 18(4), 2321-2356.

Turan, Z., Küçüköncü, D. T., Cankuvvet, N., \& Yolal, Y. (2012). Koklear implant ve işitme cihazı kullanan işitme kayıplı çocukların dil ve dinleme becerilerinin değerlendirilmesi [Evaluation of language and listening skills of the children with hearing loss who use cochlear implants and hearing aids]. Gülhane Tip Dergisi, 54, 142-150.

Uysal, H., \& Dinçer, Ç. (2013). Okul öncesi dönemde karşılaşılan fiziksel ve ilişkisel saldırganlığın bazı değişkenler açısından incelenmesi [An evaluation of physical and relational aggression duringpreschool period in relation to some variables]. Ë̆itim ve Bilim, 38(169).

Yılmaz, Ş. S., Avcığlu, E., \& Büyükçakmak, Y. (2019). Joubert Sendromunda genel gelişim, dil ve oyun becerilerinin değerlendirmesi [Assessment of general development, language and play skills in Joubert Syndrome]. Dil Konuşma ve Yutma Araştırmaları Dergisi, 2(1), 30-39. 
Zatto, B. (2018). Depressive, anxious, and somatic symptoms and teacher-child relationship quality in early childhood. Unpuplished Master Thesis, University of Alberta, Canada. 